BULLETIN OF PNRPU. GEOLOGY. OIL \& GAS ENGINEERING \& MINING

ВЕСТНИК ПНИПУ. ГЕОЛОГИЯ. НЕФТЕГАЗОВОЕ И ГОРНОЕ ДЕЛО

ISSN 2224-9923

Volume/TOM 15 №20 2016

http://vestniks.pstu.ru/geo/

УдК 622.663 .3

Article / Статья

(C) PNRPU / ПНИПУ, 2016

\title{
METHOD OF THE SEPARATE VENTILATION OF OIL MINE`S GRADIENT EXCAVATIONS AND UNDERGROUND MINE DRIFTS
}

\author{
A.V. Nikolaev \\ Perm National Research Polytechnic University (29 Komsomolskii av., Perm, 614990, Russian Federation)

\section{СПОСОБ РАЗДЕЛЬНОГО ПРОВЕТРИВАНИЯ УКЛОННЫХ БЛОКОВ И ПОДЗЕМНЫХ ГОРНЫХ ВЫРАБОТОК НЕФТЯНОЙ ШАХТЫ}

\section{А.В. Николаев}

Пермский национальный исследовательский политехнический университет (614990, Россия, г. Пермь, Комсомольский пр., 29)

Received / Получена: 16.03.2016. Accepted / Принята: 29.08.2016. Published / Опубликована: 30.09.2016

Key words:

oil mine, ventilation, natural draught, thermal depression, gradient excavation, main ventilation unit.

\begin{abstract}
On the Yarega field (LUKOIL-Komi LLC) a thermal mining oil development is applied. With such method, there is a considerable heat release in oil mines' working areas (in drilling galleries of the gradient excavations). Increasing temperature causes deterioration of hygiene and reduces miners' productivity. Activities and ways proposed and currently used to reduce the air temperature in gradient excavations require significant financial expenses for implementation - for refrigeration equipment and air heater installations of ventilation boreholes, well excavation itself, as well as for the process of the air treatment - expenses of electricity for air conditioning (cooling) and energy resources (mainly natural gas) for heating the air supplied to wells during the cold season.

This paper proposes a method of gradient excavation's ventilation, which allows the use of a natural draft's positive effect (thermal depression) arising between underground mine workings due to the temperature difference (density, specific gravity) of air in them. The proposed method will reduce the cost of electricity for ventilation, as well as decrease the temperature in oil mine's underground mine drifts. Furthermore, the proposed method does not require equipping the ventilation hole with heating system and air conditioning, which would also contribute to the energy and resource savings. In addition, natural draft will occur between the trunks of oil mines. Calculations show that it will have a positive value, that is, will facilitate ventilation. Controlling the performance and pressure developed by the main ventilation unit taking into account the action of natural draft would also reduce the electrical energy consumption for airing.
\end{abstract}

На Ярегском месторождении (ООО «ЛУКОЙЛ-Коми») применяется термошахтный способ добычи нефти. При подобном способе наблюдаются значительные тепловыделения в рабочих зонах (в буровых галереях уклонных блоков) нефтяных шахт. Повышение температуры воздуха становится причиной ухудшения санитарногигиенических норм и снижения производительности труда горнорабочих. Предложенные и используемые в настоящее время мероприятия и способы снижения температуры воздуха в уклонных блоках требуют значительных финансовых затрат: на оснащение холодильными и калориферными установками вентиляционных скважин, проходку самих скважин, а также на процесс воздухоподготовки - затраты электрической энергии на кондиционирование (охлаждение) - и энергетических ресурсов (в основном природного газа) на нагрев воздуха, подаваемого в скважины в холодное время года.

Предложен способ проветривания уклонного блока, который позволяет использовать положительное действие естественной тяги (тепловой депрессии), возникающей между подземными горными выработками вследствие разности температур (плотностей, удельного веса) воздуха в них. Предложенный способ позволит уменьшить затраты электрической энергии на проветривание, а также снизить температуру воздуха в подземных горных выработках нефтяных шахт. Помимо этого, при его использовании не требуется оснащения вентиляционных скважин системами кондиционирования и нагрева воздуха, что также будет способствовать энерго- и ресурсосбережению.

Естественная тяга будет возникать между стволами нефтяной шахты. Как показали расчеты, она будет иметь положительное значение, т.е. будет способствовать проветриванию. Регулирование производительности и давления, развиваемого главной вентиляторной установкой (с учетом действия естественной тяги) также будет способствовать снижению электрической энергии для проветривания.

Aleksandr V. Nikolaev (Author ID in Scopus: 7202396660) - PhD in Engineering, Associate Professor at the Department of Electrification and Automation of Mine Enterprises (tel.: +007 34221987 88, e-mail: nikolaev0811@mail.ru).

Николаев Александр Викторович - кандидат технических наук, доцент кафедры горной электромеханики (тел.: +007 3422198788 , е-таil: nikolaev0811@mail.ru). 


\section{Introduction}

In Yarega oil and titanium field the produced oil, on top of the high density $\left(952 \mathrm{~kg} / \mathrm{m}^{3)}\right.$, is exceptionally viscous - $16,000 \mathrm{MPa} \cdot \mathrm{s}$. This property causes the need for a uniquely designed development system in order to extract the oil reserves. Namely, the productive horizon is being treated with injected hot steam, according to the method called "thermal mining" $[1,2]$. Due to the horizon porosity, it heats up uniformly, thereby reducing oil viscosity an enabling its recovery.

The thermal mining technology applied at Yarega field is implemented essentially via the following development systems [3, 4].

1. Double-horizon development system (Figure 1) that suggests steam injection from an overlying horizon located in $10-30 \mathrm{~m}$ above the reservoir roof, via vertical and steep injection wells, while oil production is performed through gently ascending production wells up to $300 \mathrm{~m}$ long, drilled from the gallery located in the productive horizon.

2. Surface-underground development system [5] suggesting that mine operations are performed in the productive reservoir or below, while the production wells are drilled as gently tilted and are planned in rows (Figure 2). Steam distribution wells are drilled in between the production wells, wherein hot steam is injected from the surface.

The existing high viscosity oil and natural bitumen field development methods enable production of maximum 20-30\% percent of balance reserves. Yarega field development experience

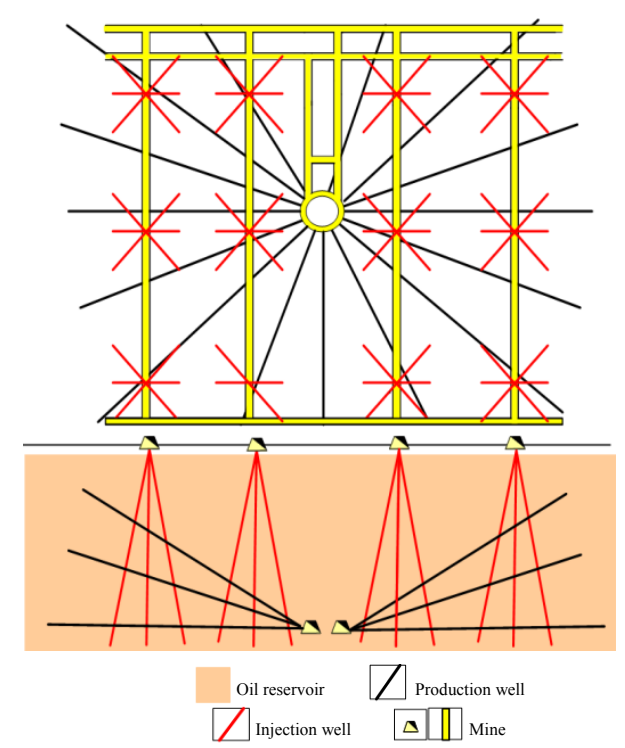

Figure 1. Double-horizon development system proves that by way of thermal mining method it is possible to produce from 50 to $70 \%$ of hydrocarbon reserves [1]. However, the underground oil recovery method, apart from high cost of steam heating required to sufficiently raise the reservoir temperature (2.7 tons of steam per 1 ton of oil in average), has another significant drawback - massive heat liberation into the mine tunnels which causes two important problems:

1. Breach of mineworker labor health requirements.

2. Reservoir heating efficiency reduction due to heat leakage into the rock, resulting in the need to use extra volumes of steam and related steam preparation financial cost increase.

Several traditional ways to solve the first problem (breach of oil mine worker labor health requirements) exist:

- increase of total amount of air supplied to the well;

- installation of a central cooling station on the surface to cool down the entire volume of air supplied to the mine (air conditioning stations);

- use of cooling machines inside the well at the entrance to the tilted sections or the drilling gallery.

The above solutions are unable to bring the desired result in the oil mine conditions; besides, their implementation requires material electric energy contribution related with operation of the main mine fan (MMF) and air conditioning system, etc. [6]. Moreover, cooling of air supplied to the tilted sections of the oil mine will result in

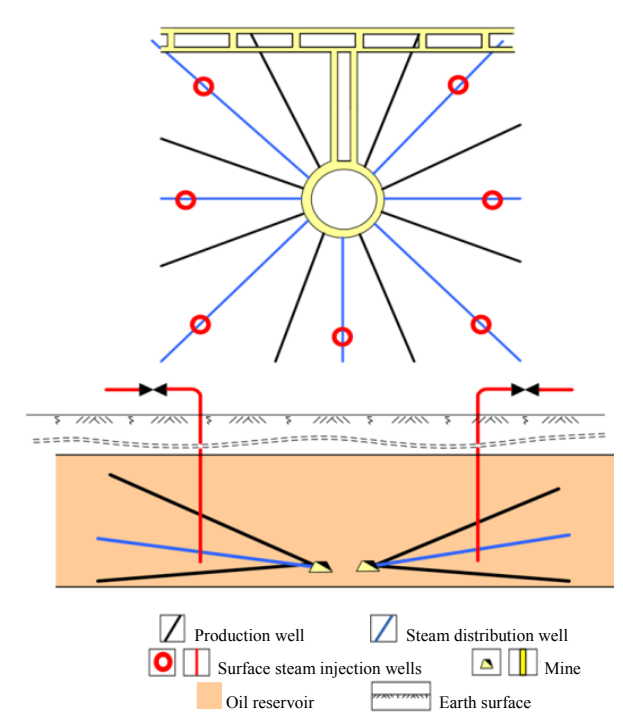

Figure 2. Surface-underground development system 
rock mass cooling, which in its turn will reduce the effect of oil production measures.

Since it appears to be impossible to eliminate both problems using traditional methods, currently efforts are made to develop alternative solutions.

For instance, study [7] suggests cooling down a jet of air in the drilling gallery using a heat exchanger unit with special purpose design [8]. In this case the problem of additional financial burden related with reservoir heating is not being solved. Besides, the heat exchanging unit efficiency is poorly proven.

In paper [9] it is suggested to perform partial heat insulation of the tilted section heated surface. It is noteworthy that heat insulation will be unable to fully eliminate heat loss due to its own heat consumption, especially as it will lose its insulating properties over time [6]. Another drawback of the proposed solution is a fact that the heat field will spread across the mine bypassing the insulation, i.e. the air will heat up beyond the boundaries of the insulating layer. Besides, due to the high cost of materials with required insulating properties and their significant quantity this option is unfeasible financially. Heat emissions from the rock mass are not exclusive. There are other sources of heat in the tilted sections, such as heated fluids, steam and condensate migrating from production wells, i.e. via uninsulated areas, constituting $60-70 \%$ of all heat emitted during the drilling gallery operations [10]. In the cited study, these other sources of heat are unaccounted for.

In paper [11] it is proposed to use a radiation conditioner for induced generation of heat balancing jackets around the mine operation areas. However this method requires material financial expenditure related to air conditioning thereby reducing reservoir temperature and resulting in oil production losses.

In view of the above mentioned, it is required to develop a method which will create satisfactory conditions in the oil mine in terms of health requirements, and, taking into account the drawbacks and high cost of heat insulation solutions, maximally use the heat produced by the rock mass.

One of the options to deal with the existing problem is to retrofit the existing and/or develop a new algorithm to vent the tilted section and oil mine in general.

\section{Oil mine tilted section ventilation methods}

The new ventilation algorithm of the oil mine tilted section can take maximum advantage of the negative phenomenon of heat loss to the mine tunnels. Since according to the convective heat exchange law warmer (lighter) air tends to move up and colder (heavier) air - to move down, a drop in hydrostatical pressure will occur between the oil mine tunnels, also referred to as "thermal depression" or "natural draught" [12-15].

Accounting for the thermal depressions in the course of ventilation algorithm development for excavation area of a potassium mine with aerodynamic parameters similar to those of the oil mine in question enabled significant improvement in the ventilation conditions and energy efficiency of venting $[16,17]$.

Based on the experience of venting algorithms development for the excavation area of a potassium mine, study [18] proposes a venting algorithm for a tilted section of the oil mine presented in Figure 3.

The main idea of the method was to use heat emission from the heated reservoir to vent the tilted section where fresh air was delivered via pass-way 1 , and removed via vent channel 3. Natural draught $h_{e}$ occurring in the process of excavation due to the temperature difference between the surface and the

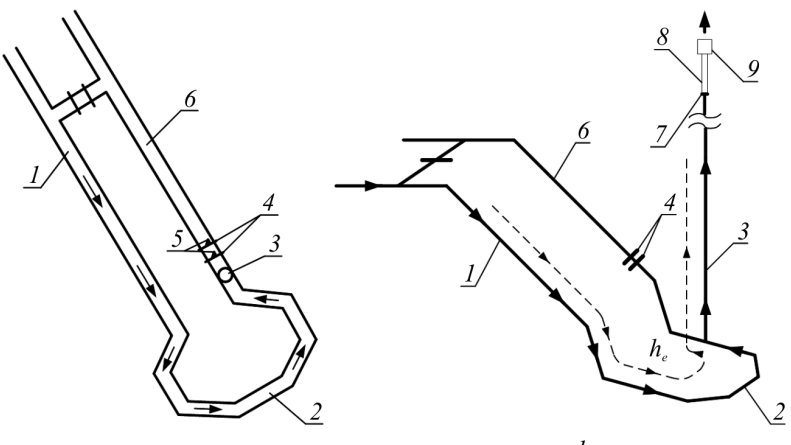

Figure 3. Simplified schematic drawing of the considered venting algorithm for the oil mine tilted section: $a$ - top view; $b$ - side view. 1 - pass-way; 2 - drilling gallery; 3 - ventilation well; 4 - air lock consisting of partitions; 5 - man gate; 6 - tilted section; 7 - well entrance; 8 - pipe; 9 - draught source (deflector or fan); $h_{e}$ - natural draught

drilling gallery 2 directs the used air to the surface. In order to improve the venting conditions, a draught source (ventilator or deflector 9) is installed on the 
surface in the ventilation well entry (pipe 8 ). Airlock consisting of partitions 4 located in tilted section 6 prevents hot air from entering the mine.

In terms of energy efficiency and maximum use of heat emission from the rock mass, the presented method is the most effective of the currently existing options. However this venting algorithm has one definitive drawback. Mine workers have to move around all the underground excavation areas, i.e. fresh air has to be delivered to all parts of the oil well. In case of emergency, mine evacuation is performed via ventilation tunnels (tunnels receiving air from the tilted sections) which are not provided by air in the described method.

In this relation, in order to improve the last described algorithm venting algorithm and provide the required amount of air to all working areas, a new venting algorithm was developed for the tilted section and oil mine in general [19], as shown in Figure 4.

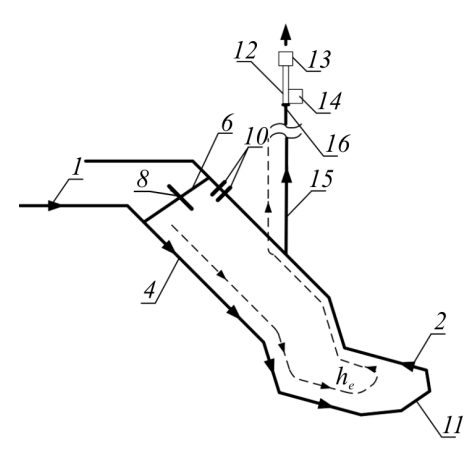

$a$

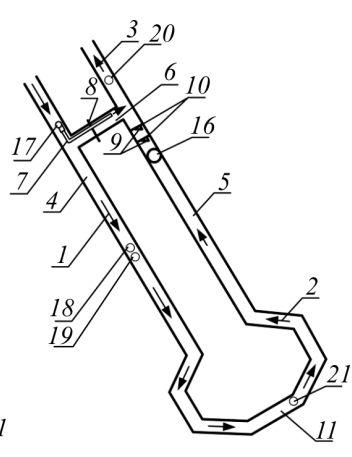

$b$
Figure 4. The proposed algorithm of oil mine tilted section venting: $a$ - top view; $b$ - side view. 1 - fresh air; 2 - heated air; 3 - outgoing air flow; 4 - pass-way; 5 - tilt; 6 - connecting tunnel; 7 - air channel in the connecting tunnel; 8 - fixed dam; 9 - door; 10 - air lock partition; 11 - drilling gallery; 12 - ventilation pipe; 13 - deflector; 14 - surface ventilator; 15 - ventilation well; 16 - ventilation well entrance; 17 - local ventilation fan; 18 - air flow sensor; 19 - temperature and pressure sensor or density meter; 20 - additional air flow sensor; 21 - additional temperature and pressure sensor or density meter

Portion of fresh air 1 with temperature equal to the rock temperature passes via the underground mine tunnels to pass-way 4 of the oil mine tilted section, and from there to the drilling gallery 11 , where it heats up and becomes lighter. Due to temperature difference between fresh air 1 , heated air 2 coming out of the drilling gallery 11 , and outer air, due to the natural draught $h_{e}$ air flow is directed to the surface of the oil mine via the ventilation well 15 . To maintain steady air flow direction in the ventilation well, it is equipped with surface draught sources in form of deflector 13 and surface ventilator 14. To prevent heated air 2 from entering the tilted section, it is equipped with an airlock consisting of two partitions 10 . For mine workers passage from the drilling gallery to the tilted section and back, the partitions are equipped with door 9 .

The advantage of the proposed algorithm is that the area behind the airlock and, consequently, the outgoing ventilation wells will be filled with fresh air owing to the local ventilation fan (LVF) 17.

In order to ensure energy efficiency and resource saving mode of the tilted section ventilation, the process of air flows distribution has to be automated.

Data from air flow sensors $(18,20)$, pressure and temperature sensors or density meters $(19,21)$ arrives to the medium level of automation programmable microcontroller (PLC). Depending on the fresh air volumetric flow required for venting of the drilling gallery and the desired health-ensuring conditions in it (to be controlled by sensors 19, 21) LVF mode of operation is selected in PLC and surface fan 14 (see Figure 4). When the depression from the natural draught $h_{e}$ is sufficient for venting of the tilted section, surface fan is deactivated. Volumetric air flow (LVF performance) is defined by the air flow sensor 20 . The required mode of operation is maintained by means of the guided electric drive.

Thus with increase of temperature in the drilling gallery, the value of natural draught $h_{e}$ will grow, i.e. without additional energy costs, the proposed algorithm improves the venting conditions, resulting in the decrease of temperature in the drilling gallery. Therefore the system is selfregulating based on the parameter of temperature in the working area.

\section{Ventilation management in the entire oil mine}

Since according to [20] MMF is one of the main power consumers (approximately $30 \%$ of the overall power consumption of the mining plant), to increase venting power efficiency taking into account operational safety requirements [21] it was propose to automate the of underground mine ventilation process.

For the proposed method of separate venting of the tilted section and oil mine in general, the working principle of the ventilation automation will be identical to the algorithm described in [21]. 
Information from temperature sensors, pressure sensors (or density meters) and air flow 14, 15, located in the entrance 12, shaft insets 13 , main outgoing ventilation tunnels 14 and in MMF channel 6 (Figure 5) will be transferred to PLC which will calculate the overall mine natural draught between the mine shafts.

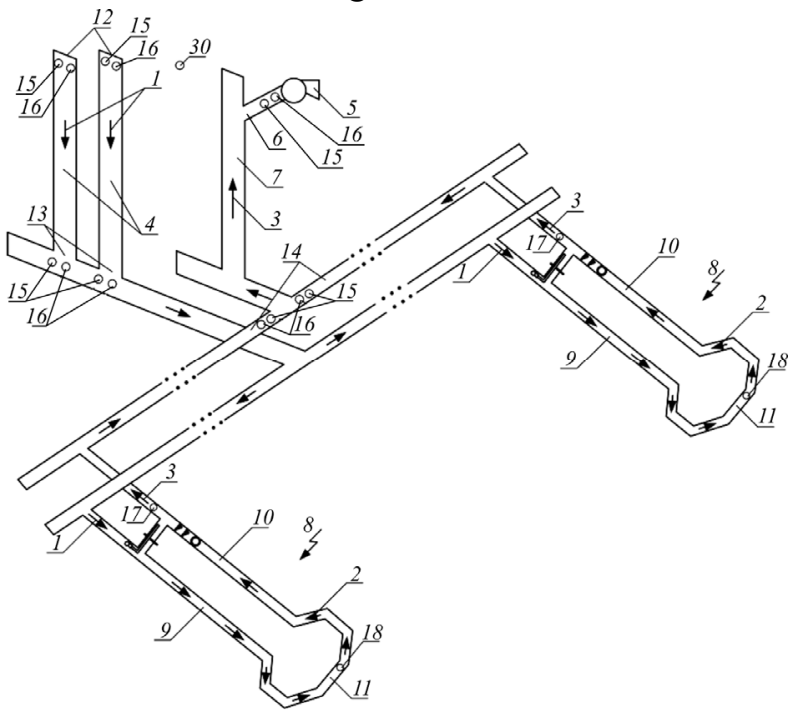

Figure 5. Method of separate ventilation of tilted sections and oil mine in general: 1 - fresh air; 2 - heated air; 3 - outgoing air flow; 4 - air intake shaft; 5 - MMF; 6 - MMF channel; 7 - oil well ventilation shaft; 8 - tilted section; 9 - pass-way; 10 - tilted section; 11 - drilling gallery; 12 - air intake shaft entrance; 13 - intake shaft inset; 14 - main outgoing ventilation tunnel; 15 - air flow sensor; 16 - temperature and pressure sensor or density meter; 17 - additional air flow sensor; 18 - additional temperature or pressure sensor or density meter

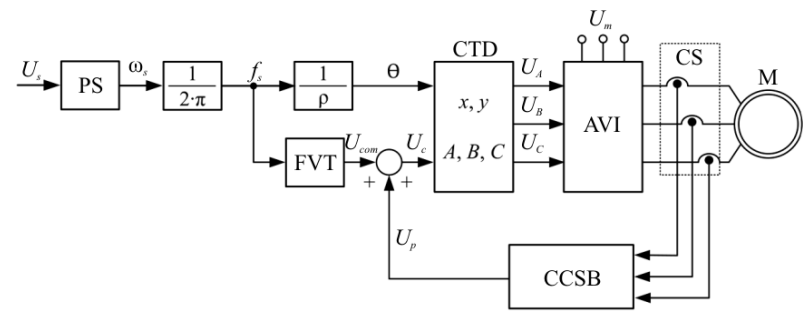

Figure 6. Implementation of forced draft ventilators electric drive control based on $\mathrm{u} / \mathrm{f}$ control scheme with $I R$-compensation: $U_{\mathrm{s}}$ - set voltage; PS - power-up sensor for change of the set velocity $\left(\omega_{\mathrm{s}}\right)$ and frequency $\left(f_{\mathrm{s}}\right)$; FVT frequency-voltage transducer; CTD - coordinates transducer for direct transformation of two-coordinate voltage system $(x, y)$ to three-phase system $\left(U_{A}, U_{B}, U_{C}\right)$ of controlled voltages of an autonomous voltage invertor (AVI); CS - three-phase current system sensor; CCSB - current compensation system builder; $U_{\mathrm{c}}-$ CTD control voltage; $U_{\text {com }}-I R$-compensation voltage; $\theta$ - angle of positioning of two-coordinate system $x, y$ of a generic electric and mechanical electric motor system; $\rho$-differentiation system; $U_{\mathrm{p}}-$ FVT voltage; $U_{\mathrm{m}}-$ mains voltage; $\mathrm{M}$ - forced fraught fan motor
The outstanding feature of the method is that apart from the above mentioned sensor data, the microcontroller will receive information from sensors installed in all tilted sections, and the role of executive devices (apart from MMF electric drive) will be performed by the electric drives of LVF and surface fans. LVF and surface ventilators control may be implemented by means of compensating voltage drop on the active stator resistance of an induction motor with squirrel cage rotor (feedforward and feedback) with $\mathrm{u} / \mathrm{f}$ control $I R$-compensation (Figure 6) [22, 23].

Depending on the natural draught value between the shafts which can be determined with a required degree of probability based on the design formulas [14, 24], it is required to regulate the MMF operating mode. Provided that the positive overall mine draught exists, it is possible to achieve a significant saving of power consumed by MMF [25].

\section{Summary}

To summarize, the method of separate ventilation of the tilted section and the entire oil mine described in this paper has following advantages in comparison with the previous methods:

1. It is proposed to use heat emission from the heated reservoir as the main source of thermal depression (natural draught) between the mine tunnels, while the existing methods are mainly focused on local temperature reduction in the working area.

2. Automation of integrated operation of LVF, surface fans of all tilted sections and MMF will help increase power efficiency of venting, i.e. to provide all oil mine areas with fresh air in the desired volume. Besides, in case the natural draught is sufficient for venting of an individual tilted section, its surface fan will be deactivated and ventilation is performed only due to the convective heat exchange (reinforced by deflector).

3. Use of LVF during venting of the tilted section will allow providing fresh unheated air to the outgoing ventilation tunnels, improving the environment therein and, in case of emergency (e.g. fire), enabling their use as evacuation ways to exit the oil mine.

4. Improvement of occupational health conditions in the drilling gallery occurs naturally without additional power expenditure. When temperature in the working area increases, natural 
draught $h_{e}$, increases as well, causing the intensification of fresh air intake into the tilted section (air temperature is relatively low approximately $9-10{ }^{\circ} \mathrm{C}$ ). Consequently the air temperature in the drilling gallery starts to decrease, resulting in the reduction of natural draught and, as a consequence, decrease of incoming fresh cooling air. Thus the venting system will be self-regulating based on its temperature depending on the occupational health conditions in the working area without additional power consumption.

\section{References}

1. Konoplev Iu.P., Buslaev V.F., Iagubov Z.Kh., Tskhadaia N.D. Ed. N.D. Tskhadaia. Termoshakhtnaia razrabotka neftianykh mestorozhdenii [Thermal mining development of oil fields]. Moscow: Nedra-Biznestsentr, 2006, 288 p.

2. Chertenkov M.V., Mulyak V.V., Konoplev Y.P. The Yarega heavy oil field - history, experience, and future. Journal of Petroleum technology, 2012, pp.158-160. DOI: 10.2118/0412-0153-JPT.

3. Tiun'kin B.A., Konoplev Iu.P. Opyt podzemnoi razrabotki neftianykh mestorozhdenii i osnovnye napravleniia razvitiia termoshakhtnogo sposoba dobychi nefti [Oil field's underground mining experience and main directions of development of thermal mining method of oil production]. Ukhta: PechorNIPIneft', 1996, 160 p.

4. Konoplev Iu.P., Guliaev V.E. Vnedrenie novykh metodov termoshakhtnoi razrabotki na Iaregskom mestorozhdenii vysokoviazkoi nefti [Introduction of new methods of thermal mining development at Yaregskoye heavy oil field]. Neftianoe khoziaistvo, 2011, no.2, pp.89-91.

5. Tiun'kin B.A., Bukreev V.M., Grutskii L.G., Konoplev Iu.P., Pranovich A.A., Pitirimov V.V., Sheshukov V.E. Sposob razrabotki mestorozhdeniia vysokoviazkoi nefti [Method of development of heavy oil field]: patent 2114289 Ros. Federatsiia: MPK E21B43/24. No. 97103294/03; zaiavlen 12.03.1997; opublikovan 27.06.1998, Biulleten' no. 8 .

6. Martynov A.A., Iakovenko A.K., Korol' V.I. $\mathrm{K}$ voprosu umen'sheniia riska teplovykh porazhenii gornorabochikh $\mathrm{v}$ vyrabotkakh glubokikh shakht [On the question of reducing the risk of thermal injuries miners in the workings of deep mines]. Gornyi informatsionnoanaliticheskii biulleten' (nauchno-tekhnicheskii zhurnal), 2004, no.5, pp.268-271.

7. Zakirov D.G., Faizrakhmanov R.A., Nikolaev A.V., Shaiakbarov N.F. Povyshenie effektivnosti podzemnoi dobychi nefti termoshakhtnym sposobom [The options to improve the underground oil extraction using the method of thermal mining development]. Neftianoe khoziaistvo, 2014, no.6, pp.58-60.

8. Zakirov D.G., Borinskikh I.I., Zakirov G.D., Mukhamedshin M.A., Guliaev V.E., Kuznetsov S.A. Teploobmennoe ustroistvo dlia okhlazhdeniia shakhtnoi ventiliatsionnoi strui [Heat-exchange device for cooling air flow in shaft]: patent 2476798 Ros Federatsiia: MPK F28S 1/00, F24F 9/00. No. 2011119716/06; zaiavlen 16.05.2011; opublikovan 27.02.2013, Biulleten' no. 6.

9. Sednev D.Iu., Krivoshchekov S.N. O vozmozhnosti primeneniia chastichnoi teploizoliatsii gornykh vyrabotok uklonnykh blokov nefteshakht Iaregskogo mestorozhdeniia dlia povysheniia energoeffektivnosti protsessa dobychi [On the possibility of the application of the partial insulation in gradient excavation of Yaregskoye oil field's mining shafts to improve the energy efficiency of production processes]. Problemy geologii $i$ osvoeniia nedr: tr. XVIII Mezhdunar. simp. im. akad. M.A. Usova studentov i molodykh uchenykh, 7-11 aprelia 2014. Tomsk: Izd-vo TPU, 2014, vol.2, pp.472-474.

10. Tskhadaia N.D., Zhuikov A.E., Iagubov Z.Kh. Kriterii otsenki optimal'nykh uslovii truda $\mathrm{v}$ gornykh vyrabotkakh neftianykh shakht [Criterion of evaluation of optimum work conditions in mining workings of oil mines]. Neftegazovoe delo, 2012, no.5, pp.318-326.

11. Boiko V.A., Boiko A.B. Sposob uskorennogo formirovaniia teplouravnivaiushchei rubashki gornoi vyrabotki glubokoi shakhty [Criterion of evaluation of optimum work conditions in mining workings of oil mines]. Gornyi informatsionno-analiticheskii biulleten' (nauchno-tekhnicheskii zhurnal), 2004, no.10, pp.86-90.

12. Bruce W.E. Natural draft: its measurement and modeling in underground mine ventilation systems. US: Dept. of Labor, Mine Safety and Health Administration, 1986, $34 \mathrm{p}$.

13. Jianwei Cheng, Yan Wu, Haiming Xu, Jin Liu, Yekang Yang, Huangjun Deng, Yi Wang. Comprehensive and integrated mine ventilation consultation model. Tunneling and Underground Space Technology, 2015, vol.45, pp.166-180. DOI:10.1016/j.tust.2014.09.004.

14. Alymenko N.I., Nikolaev A.V. Influence of mutual alignment of mine shafts on thermal drop of ventilation pressure between the shafts. Journal of Mining Science, 2011, vol.47, no.5, pp.636-642. DOI: $10.1134 /$ S1062739147050121.

15. Nikolaev A.V. Upravlenie teplovymi depressiiami v sistemakh ventiliatsii kaliinykh rudnikov [Thermal depression management of ventilation systems in potash mines]: avtoref. dis. ... kand. tekhn. nauk. Perm', 2012, 20 p.

16. Nikolaev A.V. Zavisimost' potrebleniia elektroenergii glavnoi ventiliatornoi ustanovki ot sposoba provetrivaniia dobychnykh uchastkov kaliinykh rudnikov [The influence of consumption electric power is spent for work main ventilation installation from the way ventilation underground mountain developments the potash mines]. Vestnik Permskogo natsional'nogo issledovatel'skogo politekhnicheskogo universiteta. Geologiia. Neftegazovoe $i$ gornoe delo, 2011, no.1, pp.143-151.

17. Alymenko N.I., Nikolaev A.V. Sposob provetrivaniia vyemochnogo uchastka kaliinogo rudnika pri obratnom poriadke otrabotki [Method of ventilation mining area potash mines in reverse order mining and 
quarrying]. Gornyi informatsionno-analiticheskii biulleten' (nauchno-tekhnicheskii zhurnal), 2015, no.2, pp.228-234.

18. Nikolaev A.V., Fainburg G.Z. Ob energo- i resursosberegaiushchem provetrivanii podzemnykh gornykh vyrabotok [On energy and resource-saving of underground oil mine workings]. Vestnik Permskogo natsional'nogo issledovatel'skogo politekhnicheskogo universiteta. Geologiia. Neftegazovoe i gornoe delo, 2015, no.14, pp.9298. DOI: 10.15593/2224-9923/2015.14.10.

19. Sistema provetrivaniia nefteshakhty [The system of oil shafts ventilation]: pat. 2582145 Ros. Federatsiia: E21F1/00. Zaiavitel' i patentoobladatel' FGBOU VPO «Permskii natsional'nyi issledovatel'skii politekhnicheskii universitet». No. 2015115232/03; zaiavl. 22.04.2015; opubl. 10.07.2016. Biulleten'. no. 19.

20. Starkov L.I., Zemskov A.N., Kondrashev P.I. Razvitie mekhanizirovannoi razrabotki kaliinykh rud [Progress of mechanized development of potash ore]. Perm': Izd-vo Perm. gos. tekhn. un-ta, 2007, 522 p.

21. Nikolaev A.V., Alymenko N.I., Sedunin A.M. Avtomatizirovannaia resurso- $\mathrm{i}$ energosberegaiushchaia sistema vozdukhopodgotovki shakhtnogo vozdukha [Automated resource-saving and energy efficient air preparation the main air]. Gornoe oborudovanie $i$ elektromekhanika, 2013, no.11, pp.14-18.
22. Vasil'ev E.M., Nikolaev A.V., Korolev N.A. Sistema upravleniia elektroprivodom nagnetatel'nykh ventiliatorov i setevogo nasosa dlia podderzhaniia teplovogo rezhima $\mathrm{v}$ shakhtnykh stvolakh [Control systems of electric drive air blower and power pump for maintaining the thermal regime in shafts]. Gornoe oborudovanie i elektromekhanika, 2015, no.1 (110), pp.20-24.

23. Nikolaev A.V. Avtomatizatsiia protsessa vozdukhopodgotovki na podzemnykh gornodobyvaiushchikh predpriiatiiakh [Automation of the air preparation process in underground mining enterprises]. Avtomatizatsiia. Sovremennye tekhnologii, 2016, no.1, pp.19-24.

24. Lyal'kina G. B., Nikolaev A.V. Natural draught and its direction in a mine at the preset confidence coefficient. Journal of Mining Science, 2015, vol.51, no.2, pp.342-346. DOI: 10.1134/S1062739115020180.

25. Sedunin A.M., Nikolaev A.V., Sednev D.Iu. Elektroprivod glavnoi ventiliatornoi ustanovki nefteshakhty, reguliruemyi $\mathrm{s}$ uchetom deistviia obshcheshakhtnoi estestvennoi tiagi [The electric drive the main ventilation installation on the oil mine, regulated taking into account action of general mine of natural draught]. Gornoe oborudovanie i elektromekhanika, 2012, no.11, pp.2-7.

\section{Список литературы}

1. Термошахтная разработка нефтяных месторождений / Ю.П. Коноплев, В.Ф. Буслаев, 3.Х. Ягубов, Н.Д. Цхадая; под ред. Н.Д. Цхадая. - М.: Недра-Бизнесцентр, 2006. - 288 с.

2. Chertenkov M.V., Mulyak V.V., Konoplev Y.P. The Yarega heavy oil field - history, experience, and future // Journal of Petroleum technology. - 2012. - P. 158-160. DOI: 10.2118/0412-0153-JPT.

3. Тюнькин Б.А., Коноплев Ю.П. Опыт подземной разработки нефтяных месторождений и основные направления развития термошахтного способа добычи нефти. - Ухта: ПечорНИПИнефть, 1996. - 160 с.

4. Коноплев Ю.П., Гуляев В.Э. Внедрение новых методов термошахтной разработки на Ярегском месторождении высоковязкой нефти // Нефтяное хозяйство. - 2011. - № 2. - С. 89-91.

5. Способ разработки месторождения высоковязкой нефти: пат. 2114289 Рос. Федерация: МПК Е21B43/24 / Б.А. Тюнькин, В.М. Букреев, Л.Г. Груцкий, Ю.П. Коноплев, А.А. Пранович, В.В. Питиримов, В.Е. Шешуков; заявл. 12.03.1997; опубл. 27.06.1998. - Бюл. № 8.

6. Мартынов А.А., Яковенко А.К., Король В.И. К вопросу уменьшения риска тепловых поражений горнорабочих в выработках глубоких шахт // Горный информационно-аналитический бюллетень (научнотехнический журнал). - 2004. - № 5. - С. 268-271.

7. Повышение эффективности подземной добычи нефти термошахтным способом / Д.Г. Закиров, Р.А. Файзрахманов, А.В. Николаев, Н.Ф. Шаякбаров // Нефтяное хозяйство. - 2014. - № 6. - С. 58-60.
8. Теплообменное устройство для охлаждения шахтной вентиляционной струи: пат. 2476798 Рос. Федерация: МПК F28C 1/00, F24F 9/00 / Д.Г. Закиров, И.И. Боринских, Г.Д. Закиров, М.А. Мухамедшин, В.Э. Гуляев, С.А. Кузнецов; № 2011119716/06; заявл. 16.05.2011; опубл. 27.02.2013. - Бюл. № 6.

9. Седнев Д.Ю., Кривощеков С.Н. О возможности применения частичной теплоизоляции горных выработок уклонных блоков нефтешахт Ярегского месторождения для повышения энергоэффективности процесса добычи // Проблемы геологии и освоения недр: тр. XVIII Междунар. симп. им. акад. М.А. Усова студентов и молодых ученых, г. Томск, 7-11 апреля 2014 / Нац. исслед. Томск. политехн. ун-т. - Томск: Изд-во ТПУ, 2014. - T. 2. - C. 472-474.

10. Цхадая Н.Д., Жуйков А.Е., Ягубов 3.Х. Критерий оценки оптимальных условий труда в горных выработках нефтяных шахт // Нефтегазовое дело. - 2012. - № 5. - С. 318-326.

11. Бойко В.А., Бойко А.В. Способ ускоренного формирования теплоуравнивающей рубашки горной выработки глубокой шахты // Горный информационноаналитический бюллетень (научно-технический журнал). 2004. - № 10. - C. 86-90.

12. Bruce W.E. Natural draft: its measurement and modeling in underground mine ventilation systems. - US: Dept. of Labor, Mine Safety and Health Administration, 1986. $-34 \mathrm{p}$.

13. Comprehensive and integrated mine ventilation consultation model / Jianwei Cheng, Yan Wu, Haiming $\mathrm{Xu}$, Jin Liu, Yekang Yang, Huangjun Deng, Yi Wang // 
Tunneling and Underground Space Technology. - 2015. Vol. 45. - P. 166-180. DOI: 10.1016/j.tust.2014.09.004.

14. Alymenko N.I., Nikolaev A.V. Influence of mutual alignment of mine shafts on thermal drop of ventilation pressure between the shafts // Journal of Mining Science. 2011. - Vol. 47, № 5. - P. 636-642. DOI: 10.1134/S1062739147050121.

15. Николаев А.В. Управление тепловыми депрессиями в системах вентиляции калийных рудников: автореф. дис. ... канд. техн. наук. - Пермь, 2012. $-20 \mathrm{c}$.

16. Николаев А.В. Зависимость потребления электроэнергии главной вентиляторной установки от способа проветривания добычных участков калийных рудников // Вестник Пермского национального исследовательского политехнического университета. Геология. Нефтегазовое и горное дело. - 2011. - № 1. - С. 143-151.

17. Алыменко Н.И., Николаев А.В. Способ проветривания выемочного участка калийного рудника при обратном порядке отработки // Горный информационно-аналитический бюллетень (научнотехнический журнал). - 2015. - № 2. - С. 228-234.

18. Николаев А.В., Файнбург Г.З. Об энерго- и ресурсосберегающем проветривании подземных горных выработок // Вестник Пермского национального исследовательского политехнического университета. Геология. Нефтегазовое и горное дело. 2015. - № 14. - C. 92-98. DOI: 10.15593/22249923/2015.14.10.

19. Система проветривания нефтешахты: пат. 2582145 Рос. Федерация: E21F1/00 / заявитель и патентообладатель ФГБОУ ВПО «Пермский национальный исследовательский политехнический университет». - № 2015115232/03; заявл. 22.04.2015; опубл. 10.07.2016. - Бюл. № 19.

20. Старков Л.И., Земсков А.Н., Кондрашев П.И. Развитие механизированной разработки калийных руд. Пермь: Изд-во Перм. гос. техн. ун-та, 2007. - 522 с.

21. Николаев А.В., Алыменко Н.И., Седунин А.М. Автоматизированная ресурсо- и энергосберегающая система воздухоподготовки шахтного воздуха // Горное оборудование и электромеханика. - 2013. № 11. - С. 14-18.

22. Васильев Е.М., Николаев А.В., Королев Н.А. Система управления электроприводом нагнетательных вентиляторов и сетевого насоса для поддержания теплового режима в шахтных стволах // Горное оборудование и электромеханика. - 2015. - № 1 (110). C. $20-24$.

23. Николаев А.В. Автоматизация процесса воздухоподготовки на подземных горно-добывающих предприятиях // Автоматизация. Современные технологии. -2016. - № 1. - C. 19-24.

24. Lyal'kina G.B., Nikolaev A.V. Natural draught and its direction in a mine at the preset confidence coefficient // Journal of Mining Science. - 2015. - Vol. 51, № 2. - P. 342-346. DOI: 10.1134/S1062739115020180

25. Седунин А.М., Николаев А.В., Седнев Д.Ю. Электропривод главной вентиляторной установки нефтешахты, регулируемый с учетом действия общешахтной естественной тяги // Горное оборудование и электромеханика. - 2012. - № 11. - С. 2-7.

Please cite this article in English as:

Nikolaev A.V. Method of the separate ventilation of oil mine's gradient excavations and underground mine drifts. Bulletin of PNRPU. Geology. Oil \& Gas Engineering \& Mining, 2016, vol.15, no.20, pp.293-300. DOI: 10.15593/2224-9923/2016.20.10

Просьба ссылаться на эту статью в русскоязычных источниках следующим образом:

Николаев А.В. Способ раздельного проветривания уклонных блоков и подземных горных выработок нефтяной шахты // Вестник Пермского национального исследовательского политехнического университета. Геология. Нефтегазовое и горное дело. 2016. - T.15, №20. - C.293-300. DOI: 10.15593/2224-9923/2016.20.10 